\title{
PHENOLIC COMPOUNDS FROM Sidastrum micranthum (A. St.-Hil.) FRYXELL AND EVALUATION OF ACACETIN AND 7,4'-DI-O-METHYLISOSCUTELLAREIN AS MOTULATOR OF BACTERIAL DRUG RESISTENCE
}

\author{
Roosevelt A. Gomes, Rafael R. A. Ramirez, Jéssica Karina da S. Maciel, Maria de Fátima Agra e \\ Maria de Fátima Vanderlei de Souza* \\ Laboratório de Tecnologia Farmacêutica "Delby Fernandes de Medeiros”, Centro de Ciências da Saúde, \\ Universidade Federal da Paraíba, CP 5009, 58051-970 João Pessoa - PB, Brasil \\ Vivyanne S. Falcão-Silva e José P. Siqueira-Junior \\ Departamento de Biologia Molecular, Universidade Federal da Paraíba, CP 5009, 58051-970 João Pessoa - PB, Brasil
}

Recebido em 13/12/10; aceito em 21/3/11; publicado na web em 5/5/11

\begin{abstract}
From the aerial parts of Sidastrum micranthum (A. St.-Hil.) Fryxell (Malvaceae) were isolated $m$-methoxy-p-hydroxy-benzaldehyde, $o$-hydroxy-benzoic acid, acacetin, quercetin, 7,4'-Di-O-methylisoscutellarein, genkwanin and tiliroside. These compounds were identified by data analyses of spectroscopic methods. Although acacetin and 7,4'-Di-O-methylisoscutellarein did not display relevant antibacterial activity ( $\mathrm{MIC}=256 \mu \mathrm{g} / \mathrm{mL}$ ), they modulated the activity of antibiotics, i.e. in combination with antibiotics at $64 \mu \mathrm{g} / \mathrm{mL}$ ( $1 / 4 \mathrm{MIC})$, a two-fold reduction in the MIC was observed for norfloxacin and ethidium bromide; regarding tetracycline and erythromycin a two-fold reduction in the MIC was observed only with 7,4'-Di-O-methylisoscutellarein.
\end{abstract}

Keywords: Sidastrum micranthum; Malvaceae; modulation of drug resistance.

\section{INTRODUCTION}

Malvaceae is a widespread family with about 243 genera and 4225 species, particularly distributed in tropical areas. ${ }^{1}$ Natural products extracted from plants that belong to the Malvaceae family are used in the treatment of many diseases worldwide. ${ }^{2}$ Some of these uses include snakebites, asthma, diuretic, treatment of rheumatism and gastrointestinal disorders, among others. ${ }^{3}$

Sidastrum micranthum (A. St.-Hil.) Fryxell, commonly known in Brazil as "malva-preta", consists of a small shrub belonging to the Malvaceae family. It is a neotropical species, occurring commonly in Cuba, Costa Rica, Venezuela, Guyana and Brazil. ${ }^{4}$ Furthermore, a nutriceutical (tea or infusion) made from leaves is used traditionally against bronchitis, coughs and asthma. The leaves are used in cataplasms, with hot butter and olive oil as a moisturizing agent. ${ }^{5}$

In recent years, bacterial resistance to antibiotics has become a serious public health problem that concerns almost all antibacterial agents. Efflux pumps are integral proteins of the bacterial membrane and are recognized as a major cause of bacterial resistance since they extract antibiotics from the cell. ${ }^{6}$

One option for reversing or reducing the efflux-mediated resistance is the development of modulators of drug resistance such as efflux pump inhibitions (EPI), which can potentiate antibiotic activity. Plants provide a rich source of EPIs and several compounds have already been identified as potent inhibitors. ${ }^{7}$

In our ongoing project to evaluate natural compounds isolated from plants of the Brazilian biodiversity, mainly of the Malvaceae family, as modulators of antibiotic resistance, we have already demonstrated the modulatory activity of a pentamethoxyflavone and of a glycosilated kaempferol derivative (tiliroside) isolated from Herissantia tiubae $(\mathrm{K}$. Schum) Brizicky. ${ }^{8}$ In the present work, we evaluate the flavonoids aca-

*e-mail: mfvanderlei@ltf.ufpb.br cetin and 7,4'-Di-O-methylisoscutellarein as modulators of antibiotic resistance using effluxing strains of Staphylococcus aureus.

\section{EXPERIMENTAL}

\section{Instruments and reagents}

Melting points were recorded in a Model MQAPF-302 (Microquimica Equipamentos Ltda). Isolated compounds were identified by IR (Perkin-Elmer, FT-IR-1750 and Shimadzu - IR prestige 21) and extensive 1D and 2D NMR analysis $\left({ }^{1} \mathrm{H} 200 \mathrm{MHz},{ }^{13} \mathrm{C} 50 \mathrm{MHz}-\right.$ Varian-Mercury and ${ }^{1} \mathrm{H} 500 \mathrm{MHz},{ }^{13} \mathrm{C} 125 \mathrm{MHz}$ - Bruker-AC, COSY, HSQC, HMBC, NOESY) using deuterated chloroform $\left(\mathrm{CDCl}_{3}\right)$, dimethyl sulfoxide (DMSO- $\left.\mathrm{d}_{6}\right)$ or methanol $\left(\mathrm{CD}_{3} \mathrm{OD}\right)$ as solvents.

Chromatography columns were carried out on silica gel (ASTM, 230-400 mesh, Merck) and Sephadex LH-20 (GE Healthcare BioSciences $\mathrm{AB}$ ). TLC were performed on silica gel $\mathrm{PF}_{254}$ plates and the spots were visualized under UV light ( 244 and $366 \mathrm{~nm}$ ) and by spraying with $5 \% \mathrm{FeCl}_{3}$ reagent.

\section{Plant material}

The aerial parts of Sidastrum micranthum were collected in June 2006 in the city of Santa Rita at the State of Paraíba, Brazil. A voucher specimen (Agra 6865) is deposited at the Herbarium Prof. Lauro Pires Xavier (JPB), Universidade Federal da Paraíba, Paraíba - Brazil.

\section{Extraction and isolation}

The dried aerial parts of Sidastrum micranthum were powdered $(6000 \mathrm{~g})$ and subjected to maceration with ethanol 95\%. Ethanol solution was concentrated under reduced pressure to afford $200 \mathrm{~g}$ of crude ethanol extract. The material was solubilized with ethanol:water $(8: 2)$ 
and posteriorly partitioned with hexane, chloroform, ethyl acetate and n-buthanol, resulting in $46 \mathrm{~g}$ of hexane phase, $7 \mathrm{~g}$ of chloroform phase, $6 \mathrm{~g}$ of ethyl acetate phase and $8 \mathrm{~g}$ of $n$-buthanol phase.

An aliquot of the hexane phase $(6 \mathrm{~g})$ was subjected to silica gel column chromatography and eluted with hexane, ethyl acetate and then methanol, gradually increasing the polarity, yielding 239 fractions which were combined after TLC analysis. The sub-fraction 144-151 (0.204 g) was also submitted to chromatography column over silica gel, using hexane, dichloromethane and methanol, resulting in 37 fractions, also combined by TLC. The Sub-fraction 34 led to isolation of compound $\mathbf{1}(8.0 \mathrm{mg})$.

The chloroform phase $(7.0 \mathrm{~g})$ was subjected to filtration under reduced pressure using silica gel 60 as stationary phase into a funnel of porous plate and was eluted with: hexane, ethyl acetate and methanol pure or mixture binaries. The fraction hexane-ethyl acetate (50:50) $(0.823 \mathrm{mg})$ from this procedure was flash chromatographed on silica gel column, eluting with hexane, ethyl acetate and methanol, with increasing polarity to yield 119 sub-fractions. Sub-fraction 10-13 led to isolation of compound $2(4.5 \mathrm{mg})$. Fraction ethyl acetate-methanol (50:50) was further purified by repeated CC on Sephadex LH-20 $(\mathrm{MeOH})$ yielding compound $\mathbf{3}(15 \mathrm{mg})$.

The ethyl acetate phase $(6 \mathrm{~g})$ was subjected to filtration under reduced pressure using silica gel 60 as stationary phase into a funnel of porous plate, being eluted with: hexane/ethyl acetate (30:70), (50:50), (30:70), ethyl acetate, ethyl acetate/methanol (90:10), (70:30) and (50:50), yielding the respective fractions. The fraction hexane/ethyl acetate (50:50) (218 mg) which was purified after recrystallization using hexane with drops of ethyl acetate led to isolation of compound 4 (42 mg). The fraction hexane/ethyl acetate (30:70) (160 mg) from vacuum liquid chromatography of ethyl acetate phase was submitted to chromatography over flash silica gel, eluting with hexane, ethyl acetate and methanol, yielding 74 fractions. After TLC analysis, fractions 45-58 yielded compound $\mathbf{5}$ (30 $\mathrm{mg})$. Fraction ethyl acetate $(1.21$ g) from the ethyl acetate phase was subjected to the same previous chromatographic procedure resulting in 100 fractions. Subfractions 09-11 and 66-67 were gathered and then recrystallized with acetone, yielding compound $\mathbf{6}(19 \mathrm{mg})$ and compound 7 (120 mg) respectively.

\section{Quercetin (3,7,3',4'-tetrahydroxy-flavone) (3)}

${ }^{1} \mathrm{H} \mathrm{NMR}\left(\delta, \mathrm{CD}_{3} \mathrm{OD}, 500 \mathrm{MHz}\right): 7.72(d, J=2.5 \mathrm{~Hz}, \mathrm{H}-2$ '), 7.61 $(d d, J=8.5 \mathrm{~Hz}, \mathrm{H}-6$ '), 6.87 ( $d, J=8.0 \mathrm{~Hz}, \mathrm{H}-5$ '), $6.37(d, J=2.0 \mathrm{~Hz}$, $\mathrm{H}-8), 6.17$ ( $d, J=2.0 \mathrm{~Hz}, \mathrm{H}-6) .{ }^{13} \mathrm{C}$ NMR (125 MHz): 177.3 (C-4), 165.5 (C-7), 162.4 (C-5), 158.2 (C-9), 148.7 (C-4'), 148.0 (C-2), 146.2 (C-3'), 137.2 (C-3), 124.1 (C-1'), 121.6 (C-6'), 116.2 (C-5'), 116.1 (C-2'), 104.5 (C-10), 99.2 (C-6), 99.4 (C-8).

\section{Acacetin (5,7-dihydroxy-4'-methoxy-flavone) (4)}

${ }^{1} \mathrm{H} \mathrm{NMR}\left(\delta, \mathrm{CDCl}_{3}\right.$ with drops of $\left.\mathrm{CD}_{3} \mathrm{OD}, 500 \mathrm{MHz}\right): 7.72(d, J=$ $9.0 \mathrm{~Hz}, \mathrm{H}-2$ '/6'), 6.89 (d, J = 9.0 Hz, H-3'/5'), 6.43 ( $s, \mathrm{H}-3), 6.32$ (d, $J=2 \mathrm{~Hz}, \mathrm{H}-8), 6.15(d, J=2.0 \mathrm{~Hz}, \mathrm{H}-6), 3.76\left(s, \mathrm{OCH}_{3}-4\right.$ '). ${ }^{13} \mathrm{C} \mathrm{NMR}$ (125 MHz): 182.3 (C-4), 164.0 (C-2), 163.9 (C-7), 162.5 (C-4'), 161.4 (C-5), 157.8 (C-9), 127.9 (C-2'/6'), 123.3 (C-1'), 114.3 (C-3'/5'), 104.4 (C-10), 103.6 (C-3), 99.13 (C-6), 94.1 (C-8), $55.3\left(\mathrm{OCH}_{3}-4^{\prime}\right)$.

\footnotetext{
7,4'-Di-O-methylisoscutellarein (5,8-dihydroxy-7,4'-dimethoxyflavone) (5)

${ }^{1} \mathrm{H}$ NMR $\left(\delta\right.$, DMSO-d $\left._{6}, 500 \mathrm{MHz}\right): 8.09(d d, J=7.0 \mathrm{~Hz}$ and $J$ $\left.=2.0 \mathrm{~Hz}, \mathrm{H}-2^{\prime} / 6^{\prime}\right), 7.12\left(d d, J=7.0 \mathrm{~Hz}\right.$ and $\left.J=2.0 \mathrm{~Hz}, \mathrm{H}-3^{\prime} / 5^{\prime}\right)$, $6.84(s, \mathrm{H}-3), 6.53(s, \mathrm{H}-6), 3.88\left(s, \mathrm{OCH}_{3}-7\right), 3.85\left(s, \mathrm{OCH}_{3}-4^{\prime}\right)$. ${ }^{13} \mathrm{C}$ NMR (125 MHz): 182.4 (C-4), 163.5 (C-2), 162.4 (C-4'), 154.3 (C-7), 153.0 (C-5), 144.4 (C-9), 128.5 (C-2'/6'), 126.2 (C-9), 123.0 (C-1'), 114.5 (C-3'/5'), 103.9 (C-10), 103.0 (C-3), 95.7 (C-6), 56.3 $\left(\mathrm{OCH}_{3}-7\right), 55.6\left(\mathrm{OCH}_{3}-4^{\prime}\right)$.
}

Genkwanin (5,4'-dihydroxy-7-methoxy-flavone) (6)

${ }^{1} \mathrm{H}$ NMR $\left(\delta, \mathrm{DMSO}_{-}, 500 \mathrm{MHz}\right): 7.94(d, J=9.0 \mathrm{~Hz}$, H-2'/6'), $7.08\left(d, J=9.0 \mathrm{~Hz}, \mathrm{H}-3^{\prime} / 5^{\prime}\right), 6.63(s, \mathrm{H}-3), 6.46(d$, $J=2.0 \mathrm{~Hz}, \mathrm{H}-8), 6.21(d, J=2.0 \mathrm{~Hz}, \mathrm{H}-6), 3.88\left(s, \mathrm{OCH}_{3}-7\right)$. ${ }^{13} \mathrm{C}$ NMR (125 MHz): 181.9 (C-4), 165.1 (C-7), 164.11 (C-2), 161.3 (C-4'), 161.2 (C-5), 157.2 (C-9), 116.0 (C-3'/5'), 128.5 (C-2'/6'), 121.1 (C-1'), 104.7 (C-10), 103.0 (C-3), 97.9 (C-6), 92.7 (C-8),56.61 $\left(\mathrm{OCH}_{3}-7\right)$.

\section{Tiliroside [Kampherol-3-O- $\beta-D-(6 ”-E-p$-coumaroil) glicosídeo]} (7)

${ }^{1} \mathrm{H}$ NMR $\left(\delta, \mathrm{CD}_{3} \mathrm{OD}, 200 \mathrm{MHz}\right): 7.96\left(d, J=9.0 \mathrm{~Hz}, \mathrm{H}-2^{\prime} / 6^{\prime}\right)$, $7.38(d, J=15.9 \mathrm{~Hz}, \mathrm{H}-\beta), 7.25(d, J=8.6 \mathrm{~Hz}, \mathrm{H}-2$ '"'/6"' $), 6.79(d$, $J=9.0 \mathrm{~Hz}, \mathrm{H}-3$ ' $\left./ 5^{\prime}\right), 6.77$ ( $\left.d, J=8.6 \mathrm{~Hz}, \mathrm{H}-3^{\prime}{ }^{\prime} / 5^{\prime}, "\right), 6.27$ (d, $J=$ $2.0 \mathrm{~Hz}, \mathrm{H}-8), 6.11(d, J=2.0 \mathrm{~Hz}, \mathrm{H}-6), 6.05$ ( $d, J=15.9 \mathrm{~Hz}, \mathrm{H}-\alpha)$, 5.23 ( $d, J=7.6 \mathrm{~Hz}, \mathrm{H}-1$ "), 4.19 ( $d d, J=11.8$ and $2.2 \mathrm{~Hz}, \mathrm{H}-6$ "), 4.06 ( $d d, J=11,6$ and $J=6,4 \mathrm{~Hz}, \mathrm{H}-6 ")$ 3.38-3.34 ( $m, \mathrm{H}-2$ ", 3", 4"), 3,25-3,16 (m, H-5"). RMN ${ }^{13} \mathrm{C}$ (50 MHz): 179.3 (C-4), 168.8 (COO), 165.7 (C-7), 162.8 (C-5), 161.4 (C-4'), 161.0 (C-4'”), 159.2 (C-2), 158.2 (C-9), 146.5 (CH- $\beta$ ) 135.2 (C-3), 132.1 (CH2'/CH-6'), 131.1 (CH-2'”/6'”), 127.0 (C-1'”), 122.6 (C-1'), 116.7 (CH-3"'/5"'), 115.9 (CH-3'/5'), 114.7 (CH- $\alpha), 105.5$ (C-10), 104.0 (CH-1"), 99.9 (CH-6), 94.8 (CH-8), 77.9 (CH-3"), 75.7 (CH-2", CH-5"), 71.6 (CH-4"), 64.3 (CH2-6").

\section{Bacterial strains}

Three strains of S. aureus were used: SA-1199B, which overexpresses the norA gene encoding the NorA efflux protein which extrudes hydrophilic fluorquinolones and other drugs such as DNAintercalating dyes; ${ }^{9}$ RN4220 harboring plasmid pUL5054, which carries the gene encoding the MsrA macrolide efflux protein; ${ }^{10}$ and IS-58, which possesses the TetK tetracycline efflux protein. ${ }^{11}$ The strains, kindly provided by Prof. S. Gibbons (University of London), were maintained on blood agar base (Laboratórios Difco Ltda., Brazil) slants and, prior to use, the cells were grown overnight at $37{ }^{\circ} \mathrm{C}$ in brain heart infusion broth (BHI - Laboratórios Difco Ltda., Brazil).

\section{Antibiotics, ethidium bromide and flavonoids}

Norfloxacin, erythromycin, tetracycline and ethidium bromide were obtained from Sigma Aldrich Co. Ltd. The stock solutions of the antibiotics were prepared according to CLSI guidelines, ${ }^{12}$ and the ethidium bromide in sterile distilled water. The stock solution of acacetin and 7,4'-di-O-methylisoscutellarein were prepared in DMSO, and its highest concentration remaining after dilution into broth (4\%) caused no inhibition of bacterial growth.

\section{Drug susceptibility testing and modulation assay}

The minimum inhibitory concentrations (MICs) of the antibiotics, ethidium bromide and flavonoids were determined in $\mathrm{BHI}$ by the microdilution assay using a suspension of $c a .10^{5} \mathrm{cfu} / \mathrm{mL}$ and a drug concentration range of 256 to $0.5 \mu \mathrm{g} / \mathrm{mL}$ (two-fold serial dilutions). The MIC is defined as the lowest concentration at which no growth is observed. A solution of resazurin $(0.01 \% \mathrm{w} / \mathrm{v}$ in sterile distillated water) was used to detect bacterial growth by a color change from blue to pink. For the evaluation of flavonoids as modulators of drug resistance, the 'modulation assay' was used, a method that has been widely applied to identify potential EPIs,${ }^{13}$ i.e. the MICs of the antibiotics were determined in the presence of the flavonoids (in the BHI) at a sub-inhibitory concentration. 
<smiles>[R][R]c1ccc(-c2oc3c([R2])c([R])cc(O)c3c(=O)c2[R])cc1[R]</smiles>

(3): $\mathrm{R}=\mathrm{OH}, \mathrm{R}_{1}=\mathrm{OH}, \mathrm{R}_{2}=\mathrm{H}, \mathrm{R}_{3}=\mathrm{OH}, \mathrm{R}_{4}=\mathrm{OH}$

(4): $\mathrm{R}=\mathrm{H}, \mathrm{R}_{4}=\mathrm{OH}, \mathrm{R}_{2}=\mathrm{H}, \mathrm{R}_{3}=\mathrm{H}, \mathrm{R}_{4}=\mathrm{OCH}_{3}$

(5): $\mathrm{R}=\mathrm{H}, \mathrm{R}_{1}=\mathrm{OCH}_{3}, \mathrm{R}_{2}=\mathrm{OH}, \mathrm{R}_{3}=\mathrm{H}, \mathrm{R}_{4}=\mathrm{OCH}_{3}$

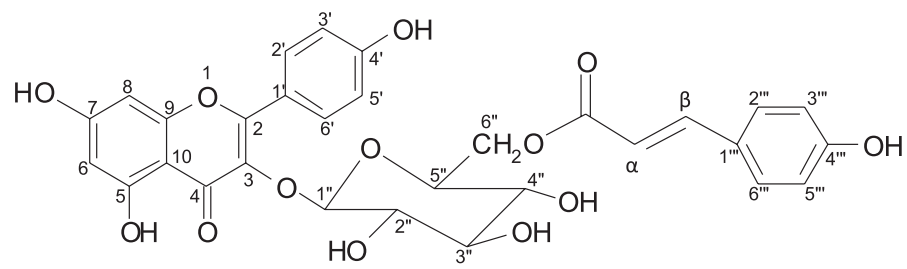

Figure 1. Compounds isolated from Sidastrum micranthum

\section{RESULTS AND DISCUSSION}

The structural assignments of compounds $\mathbf{1}$ and $\mathbf{2}$ were made based on the spectral analysis and are in good agreement with those reported in the literature. Thus, their structures were identified as Vanillin ${ }^{14}$ and salicylic acid. ${ }^{15}$ The structural identifications of the compounds 3-7 were based on spectral analysis and also by comparison with literature data, which allowed their assignments as quercetin (3) ${ }^{16}$ acacetin (4), ${ }^{17} 7,4^{\prime}$-Di-O-methylisoscutellarein (5), ${ }^{18}$ Genkwanin (6), ${ }^{17}$ and tiliroside (7). ${ }^{19}$ This is the first study reporting the presence of these compounds in Sidastrum micranthum and the first report of the compounds $\mathbf{4 , 5}$, and $\mathbf{6}$ from the Malvaceae family.

The IR spectrum of compound $\mathbf{5}$ showed a hydroxyl signal at $3458 \mathrm{~cm}^{-1}$, a conjugated carbonyl hydroxyl absorbance at $1665 \mathrm{~cm}^{-1}$ and aromatic $\mathrm{C}=\mathrm{C}$ stretching absorptions at 1609 and $1510 \mathrm{~cm}^{-1}$. The ${ }^{1} \mathrm{H}$ NMR spectra showed a pair of double doublets at $\delta_{\mathrm{H}} 8.09(J=7.0$ $\mathrm{Hz}$ and $J=2.0 \mathrm{~Hz})$ and $\delta_{\mathrm{H}} 7.12(J=7.0 \mathrm{~Hz}$ and $J=2.0 \mathrm{~Hz})$, which suggests an AA'BB'-type system of hydrogens bonded to aromatic carbon. A methoxyl group in one of the aromatic nuclei was inferred by the signal at $\delta_{\mathrm{H}} 3.88$.

The ${ }^{13} \mathrm{C}$ NMR spectral data strengthened the information provided by the ${ }^{1} \mathrm{H}$ NMR spectra, emphasizing the presence of the AA'BB' system due to signal at $\delta_{\mathrm{C}} 128.5$ and $\delta_{\mathrm{C}} 114.5$.

The positions of methoxyl groups were established by HMBC spectrum, which showed interactions between the absorptions at $\delta_{\mathrm{H}}$ $3.85\left(s, \mathrm{OCH}_{3}-4^{\prime}\right)$ and $\delta_{\mathrm{C}} 162.4\left(\mathrm{C}-4^{\prime}\right)$. In addition to interactions between the absorptions at $\delta_{\mathrm{H}} 3.88\left(s, \mathrm{OCH}_{3}-7\right) \delta_{\mathrm{C}} 154.3(\mathrm{C}-7)$. Trough the analysis of NOESY spectrum was possible to strengthen the positions of methoxyl groups by correlations between the absorptions $\delta_{\mathrm{H}}$ $3.88\left(s, \mathrm{OCH}_{3}-7\right)$ and $\delta_{\mathrm{H}} 6.53(s, \mathrm{H}-6)$. In addition to the interactions between absorptions at $\delta_{\mathrm{H}} 3.85\left(s, \mathrm{OCH}_{3}-4^{\prime}\right)$ and $\delta_{\mathrm{H}} 7.12(d, J=9.0$ $\left.\mathrm{Hz}, \mathrm{H}-3^{\prime} / 5^{\prime}\right)$. Some others assignments for the two-dimensional spectra (HMBC and NOESY) are shown in Figure 2.

The combination of spectral analysis of IR spectroscopy, ${ }^{1} \mathrm{H}$ and ${ }^{13} \mathrm{C}$ nuclear magnetic resonance, with aid of two dimensional techniques, and by the comparisons with literature data, have ratified the structure $\mathbf{5}$ as being 7,4'-di-O-methylisoscutellarein, flavonoid unpublished in the Malvaceae family.

\section{Modulation of antibiotic activity}

Acacetin and 7,4'-Di-O-methylisoscutellarein showed no antibacterial activity at $256 \mu \mathrm{g} / \mathrm{mL}$ against any strains of $S$. aureus used. When the compounds were incorporated into the growing medium at $64 \mu \mathrm{g} / \mathrm{mL}$ ( $1 / 4 \mathrm{MIC})$, a two-fold reduction in the MIC was observed

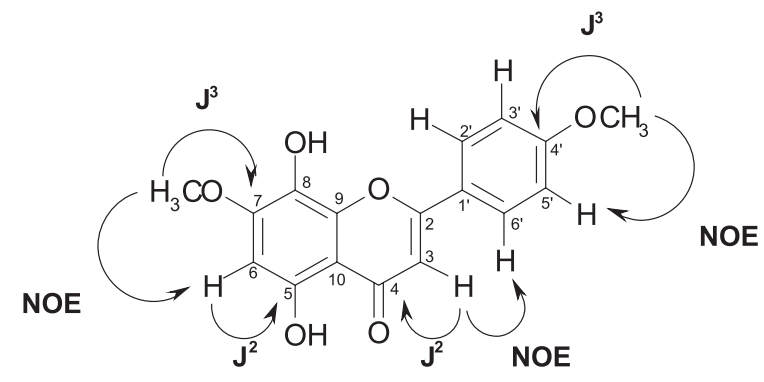

Figure 2. Some correlations observed at the HMBC $\left(J^{n}\right)$ and NOESY (NOE) spectra of 5

for norfloxacin and ethidium bromide. Regarding tetracycline and erythromycin a two-fold reduction in the MIC was observed only with 7,4'-Di-O-methylisoscutellarein. All experiments were carried out at least twice with similar results (Table 1).

Table 1. Minimum inhibitory concentrations (MICs) of antibiotics and ethidium bromide in the absence and presence of acacetin or 7,4'-Di-Omethylisoscutellarein against effluxing strains of Staphylococcus aureus strain

\begin{tabular}{|c|c|c|c|}
\hline \multirow[t]{2}{*}{ Strain (drug) } & \multicolumn{3}{|c|}{$\operatorname{MIC}(\mu \mathrm{g} / \mathrm{mL})$} \\
\hline & Alone & $\begin{array}{c}+\mathrm{ACA} \\
(64 \mu \mathrm{g} / \mathrm{mL})\end{array}$ & $\begin{array}{c}\text { + DMIS } \\
(64 \mu \mathrm{g} / \mathrm{mL})\end{array}$ \\
\hline 1199B (norfloxacin) & 64 & $32(2)^{\mathrm{a}}$ & $32(2)$ \\
\hline 1199B (ethidium bromide) & 32 & $16(2)$ & $16(2)$ \\
\hline IS-58 (tetracycline) & 32 & $32(0)$ & $16(2)$ \\
\hline RN-4220 (erythromycin) & 256 & $256(0)$ & $128(2)$ \\
\hline
\end{tabular}

ACA, acacetin; DMIS, 7,4'-Di-O-methylisoscutellarein. a (fold reduction in MIC).

The flavonoids modulated activities of the antibiotics by reducing the concentration of antibiotics needed to inhibit the growth of the drug resistant efflluxing bacteria. At least regarding tetracycline and erythromycin, 7,4'-Di-O-methylisoscutellarein can be favorably compared with acacetin, which may be related to its higher lipophilicity due to an additional methoxyl group at C-7, since lipophilicity is a common feature of several EPIs and may be a key factor for the inhibition in Gram-positive bacteria. ${ }^{13}$ Ethidium bromide is a well known substrate for NorA efflux protein, and active efflux is the only 
known mechanism of resistance to this DNA-intercalating dyes. ${ }^{20}$ Therefore, the use of ethidium bromide against the strain SA-1199B is of worth to demonstrate that the flavonoids evaluated in this case modulated the resistance to norfloxacin by inhibition of efflux pump.

Some methoxylated flavones that potentiate the activity of antimicrobial drugs have been described. ${ }^{21}$ However, as far as we know, neither acacetin nor 7,4'-Di-O-methylisoscutellarein had been previously evaluated. The present finding indicates that plants of the Malvaceae family could be useful as a source of potential adjuvant of antibiotics.

\section{SUPPLEMENTARY MATERIAL}

Available at http://quimicanova.sbq.org.br, in PDF file, with free access.

\section{ACKNOWLEDGMENTS}

J. P. Siqueira-Junior and V. S. Falcão-Silva are very grateful to Dr. S. Gibbons (University of London) for his valuable and kind cooperation. Appreciation is extended to V. C. O. Costa/LMCA-UFPB and to CENAUREN-UFC for the acquisition of NMR spectra. This work was supported by the following Brazilian agencies: CNPq, CAPES and FAPESQ-PB.

\section{REFERENCES}

1. Costa, D. A.; Silva, D. A.; Cavalcanti, A. C.; Medeiros, M. A. A.; Lima, J. T.; Cavalcante, J. M. S.; Silva, B. A.; Agra, M. F.; Souza, M. F. V.; Quim. Nova 2007, 30, 901.

2. Maganha, E. G.; Halmenschlager, R. C.; Rosa, R. M.; Henriques, J. A. P.; Ramos, A. L. K. P.; Saffi, J.; Food Chem. 2009, 118, 1.

3. Darwish, F. M. M.; Reinecke, M. G.; Phytochemistry 2003, 62, 1179; Silva, D. A.; Chaves, M. C. O.; Costa, D. A.; Moraes, M. R. R.; Nóbrega, F. B. P.; Souza, M. F. V; Pharm. Biol. 2005, 43, 197; Franzotti, E. M.; Santos, C. V. F.; Rodrigues, H. M. S. L.; Mourão, R. H. V.; Andrade, M. R.; Antoniolli, A. R. J.; J. Ethnopharmacol. 2000, 72, 273.

4. Bovini, M. G.; Carvalho-Okano, R. M.; Vieira, M. F.; Rodriguésia 2001, $52,17$.
5. Agra, M. F.; Baracho, G. S.; Basílio, I. J. D.; Nurit, K.; Coelho, V. P.; Barbosa, D. A.; Oecol. Bras. 2007, 11, 323.

6. Webber, M. A.; Piddock, L. J. V.; J. Antimicrobrob. Chemother. 2003, 51, 9; Piddock, L. J. V.; Clin. Microbiol. Rev. 2006, 19, 382.

7. Gibbons, S.; Phytochem. Rev. 2005, 4, 63; Gibbons, S.; Planta Med. 2008, 74, 597.

8. Silva, D. A.; Falcão-Silva, V. S.; Gomes, A. Y. S.; Costa, D. A.; Lemos, V. S.; Agra, M. A.; Braz-Filho, R.; Siqueira-Júnior, J. P.; Souza, M. F. V.; Pharm. Biol. 2009, 47, 128; Falcão-Silva, V. S.; Silva, D. A.; Souza, M. F. V.; Siqueira-Junior, J. P.; Phytother. Res. 2009, 23, 1367.

9. Kaatz, G. W.; Seo, S. M.; Ruble, C. A.; Antimicrob. Agents Chemother. 1993, 37, 1086; Kaatz, G. W.; Seo, S. M.; Antimicrob. Agents Chemother. 1995, 39, 2650.

10. Ross, J. I.; Farrell, A. M.; Eady, E. A.; Cove, J. H.; Cunliffe, W. J.; J. Antimicrob. Chemother. 1989, 24, 851.

11. Gibbons, S.; Udo, E. E.; Phytother. Res. 2000, 14, 139.

12. CLSI - Clinical and Laboratory Standards Institute/NCCLS; Performance Standards for Antimicrobial Susceptibility Testing; Fifteenth Informational Supplement, CLSI/NCCLS document M100-S15, Clinical and Laboratory Standards Institute: Wayne, 2005.

13. Stavri, M.; Piddock, L. J. V.; Gibbons, S.; J. Antimicrob. Chemother. 2007, 59, 1247

14. Tenailleau, E.; Lancelin, P.; Robins, R. J.; Akoka, S.; Anal. Chem. 2004, 76,3818

15. Tomaz, A. C. A., Nogueira, R. B. S. S., Pinto, D. S., Agra, M. F. Souza, M. F. V.; Cunha. E. V. L., Braz. J. Pharmacogn. 2008, 18, 47.

16. Luo, W.; Zhao, M.; Yang, B.; Shen, G.; Rao, G.; Food Chem. 2009, 114, 499.

17. Park, Y.; Moon, B.; Yang, H.; Lee, Y.; Lim, Y.; Magn. Reson. Chem. 2007, 45, 1072 .

18. Horie, T.; Ohtsuru, Y.; Shibata, K.; Yamashita, K.; Tsukawama, M.; Kawamura, Y.; Phytochemistry 1998, 47, 865.

19. Cavalcante, J. M. S.; Nogueira, T. B. S. S.; Tomaz, A. C. A.; Silva, D. A.; Agra, M. F.; Carvalho, P. R. C.; Ramos, S. R. R.; Nascimento, S. C.; Gonçalves-Silva, T.; Souza, M. F. V.; Quim. Nova 2010, 33, 846.

20. Markham, P. H.; Westhaus, E.; Klyachko, K.; Johnson, M. E.; Neyfakh, A. A.; Antimicrob. Agents Chemother. 1999, 43, 2404

21. Guz, N. R.; Stermitz, F. R.; Johnson, J. B.; Beeson, T. D.; Willen, S.; Hsiang, J. F.; Lewis, K.; J. Med. Chem. 2001, 44, 261. 
PHENOLIC COMPOUNDS FROM Sidastrum micranthum (A. St.-Hil.) FRYXELL AND EVALUATION OF ACACETIN AND 7,4'-DI-O-METHYLISOSCUTELLAREIN AS MOTULATOR OF BACTERIAL DRUG RESISTENCE

Roosevelt A. Gomes, Rafael R. A. Ramirez, Jéssica Karina da S. Maciel, Maria de Fátima Agra e Maria de Fátima Vanderlei de Souza*

Laboratório de Tecnologia Farmacêutica "Delby Fernandes de Medeiros”, Centro de Ciências da Saúde, Universidade Federal da Paraíba, CP 5009, 58051-970 João Pessoa - PB, Brasil

Vivyanne S. Falcão-Silva e José P. Siqueira-Junior

Departamento de Biologia Molecular, Universidade Federal da Paraíba, CP 5009, 58051-970 João Pessoa - PB, Brasil

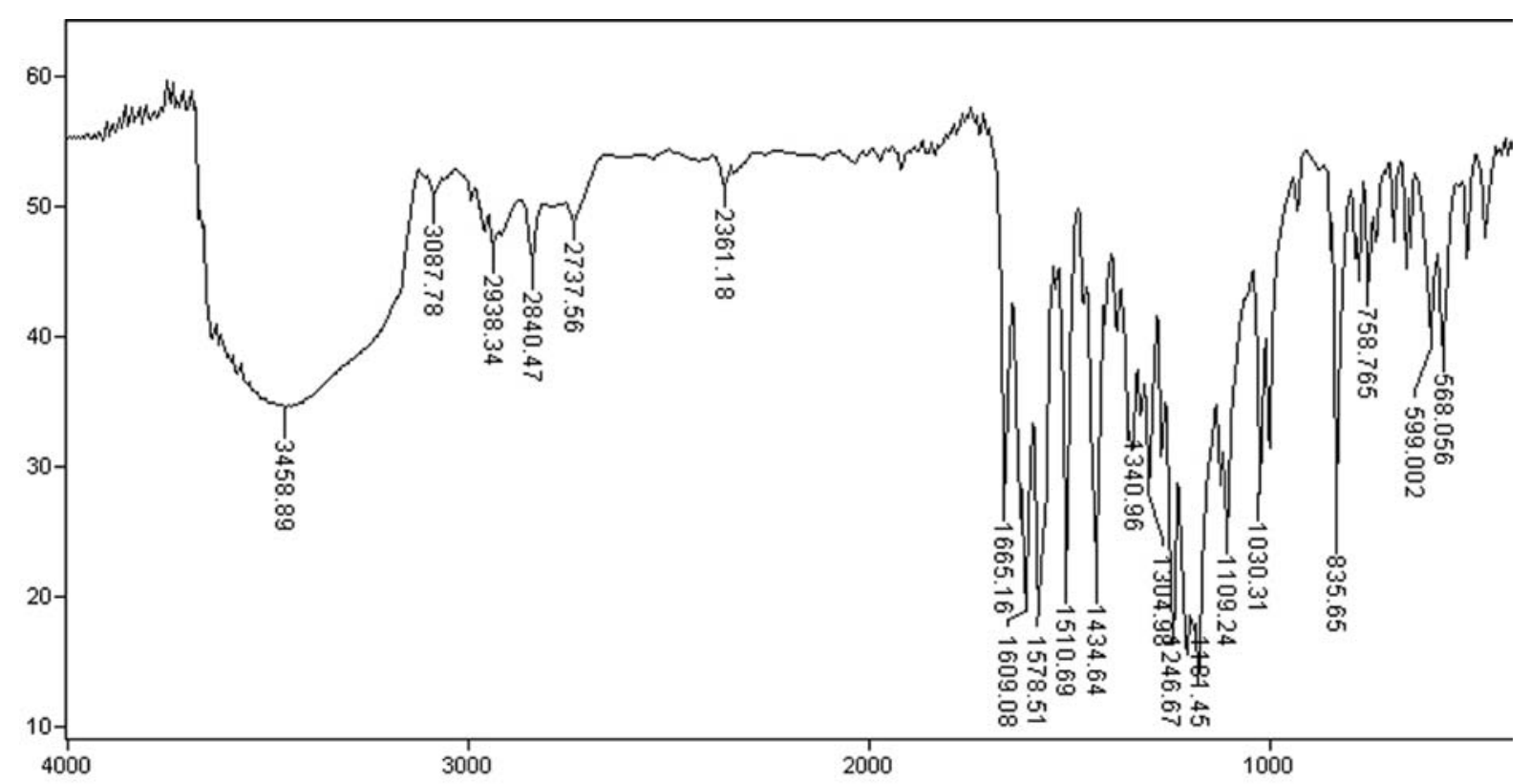

Figure IS. IR spectrum of $5\left(\mathrm{KBr}, \mathrm{cm}^{-1}\right)$ 


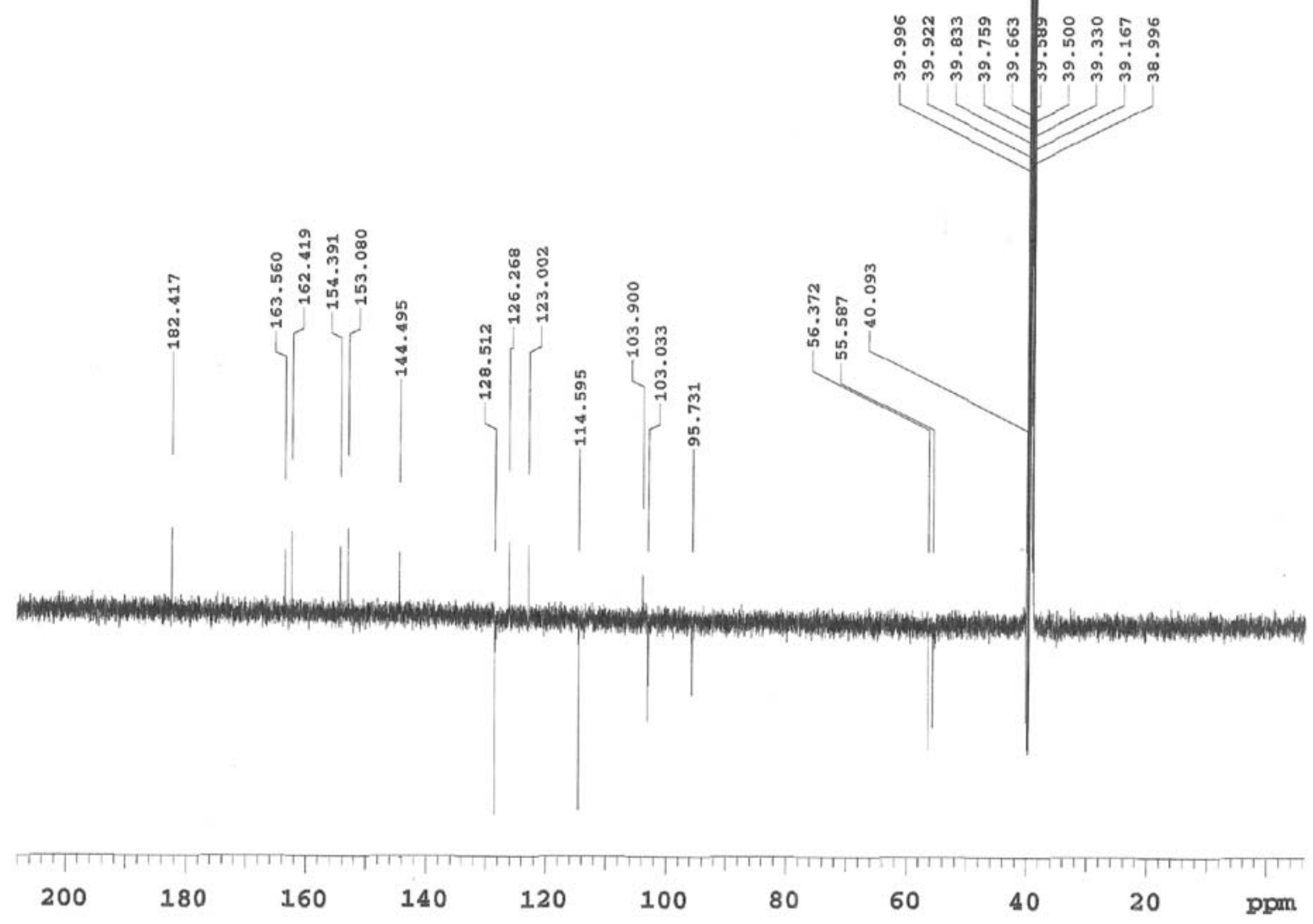

Figure $2 S .{ }^{13} \mathrm{C}$ NMR spectrum of $5\left(\delta, D M S O-d_{6}, 125 \mathrm{MHz}\right)$

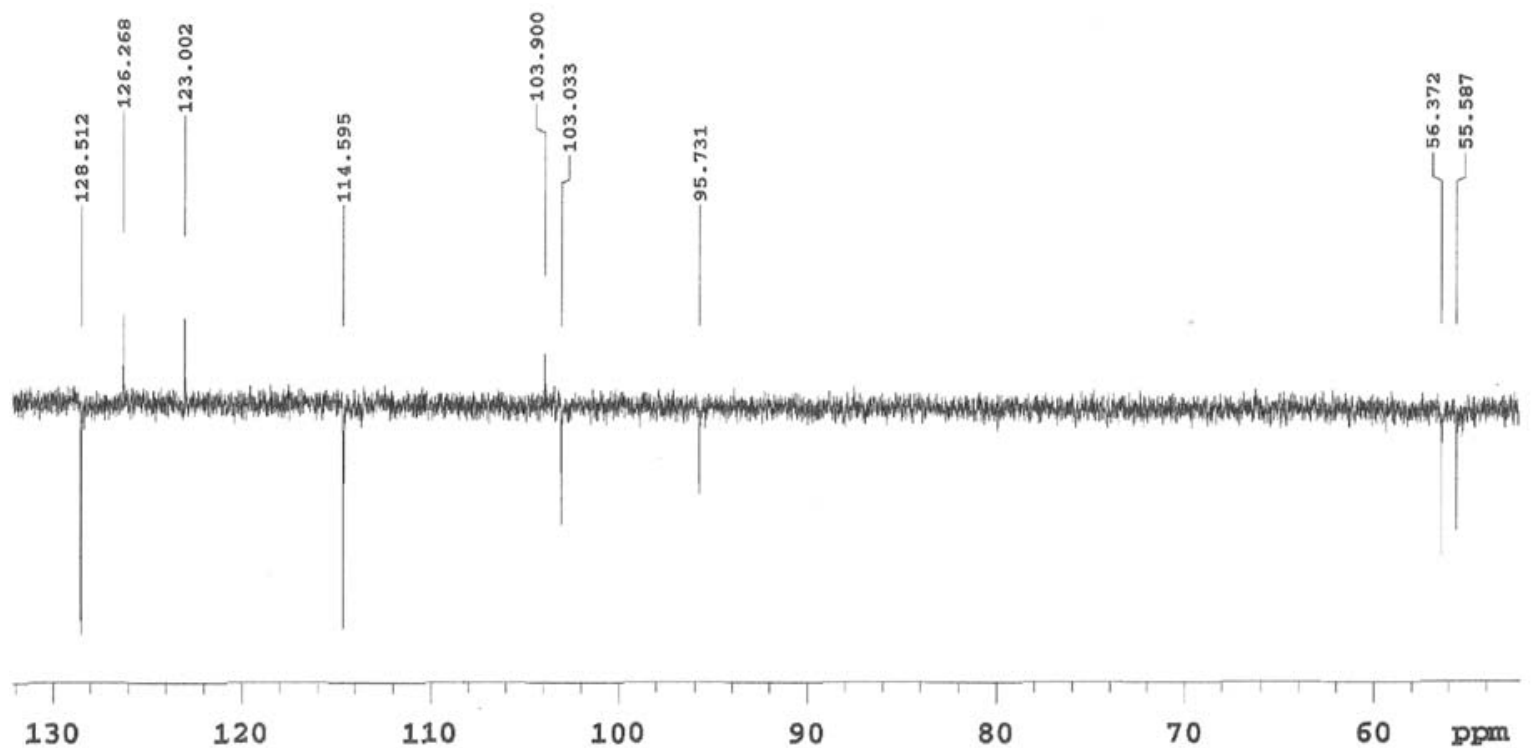

Figure 3S. Expansion of the ${ }^{13} \mathrm{C}$ NMR spectrum of $5\left(\delta, D M S O-d_{6}, 125 \mathrm{MHz}\right)$ 

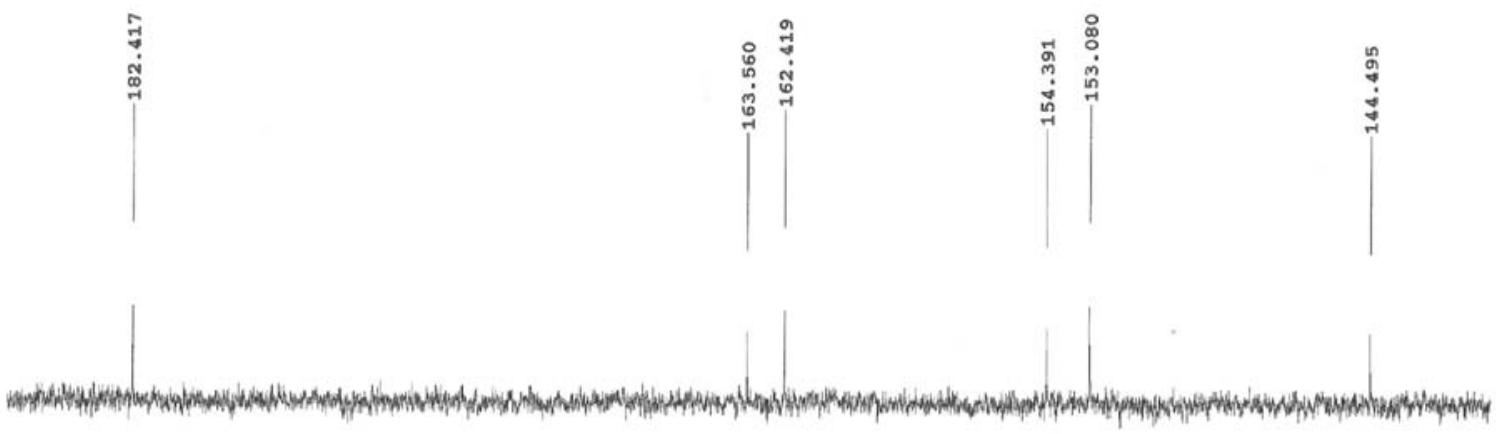

\begin{tabular}{|c|c|c|c|c|c|c|c|c|}
\hline 185 & 180 & 175 & 170 & 165 & 160 & 155 & 150 & 145 \\
\hline
\end{tabular}

Figure 4S. Expansion of the ${ }^{13} \mathrm{C}$ NMR spectrum of $5\left(\delta, D M S O-d_{6}, 125 \mathrm{MHz}\right)$

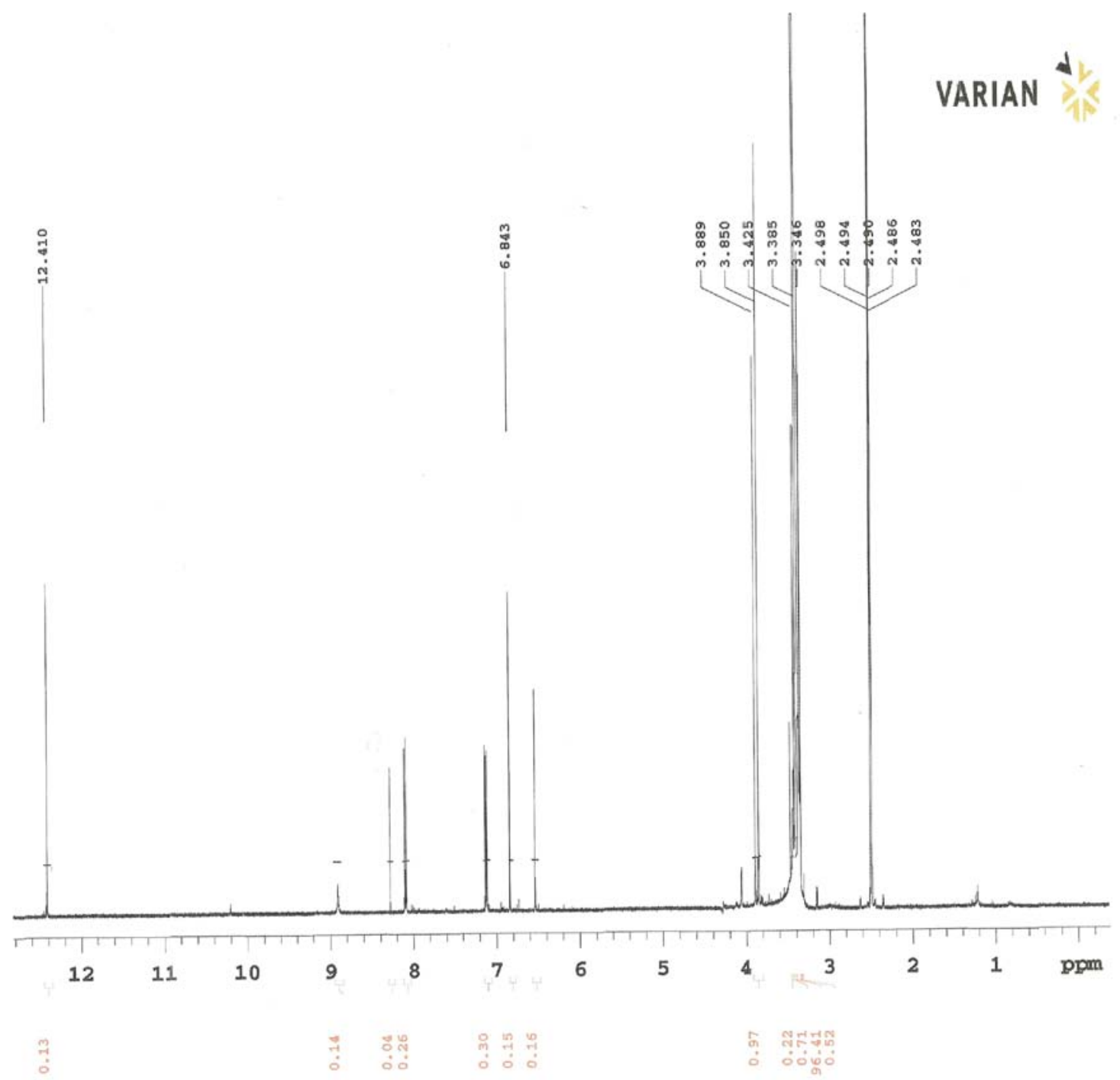

Figure 5S. ${ }^{1} \mathrm{H} N M R$ spectrum of $5\left(\delta, D M S O-d_{6}, 500 \mathrm{MHz}\right)$ 


\section{VARIAN}

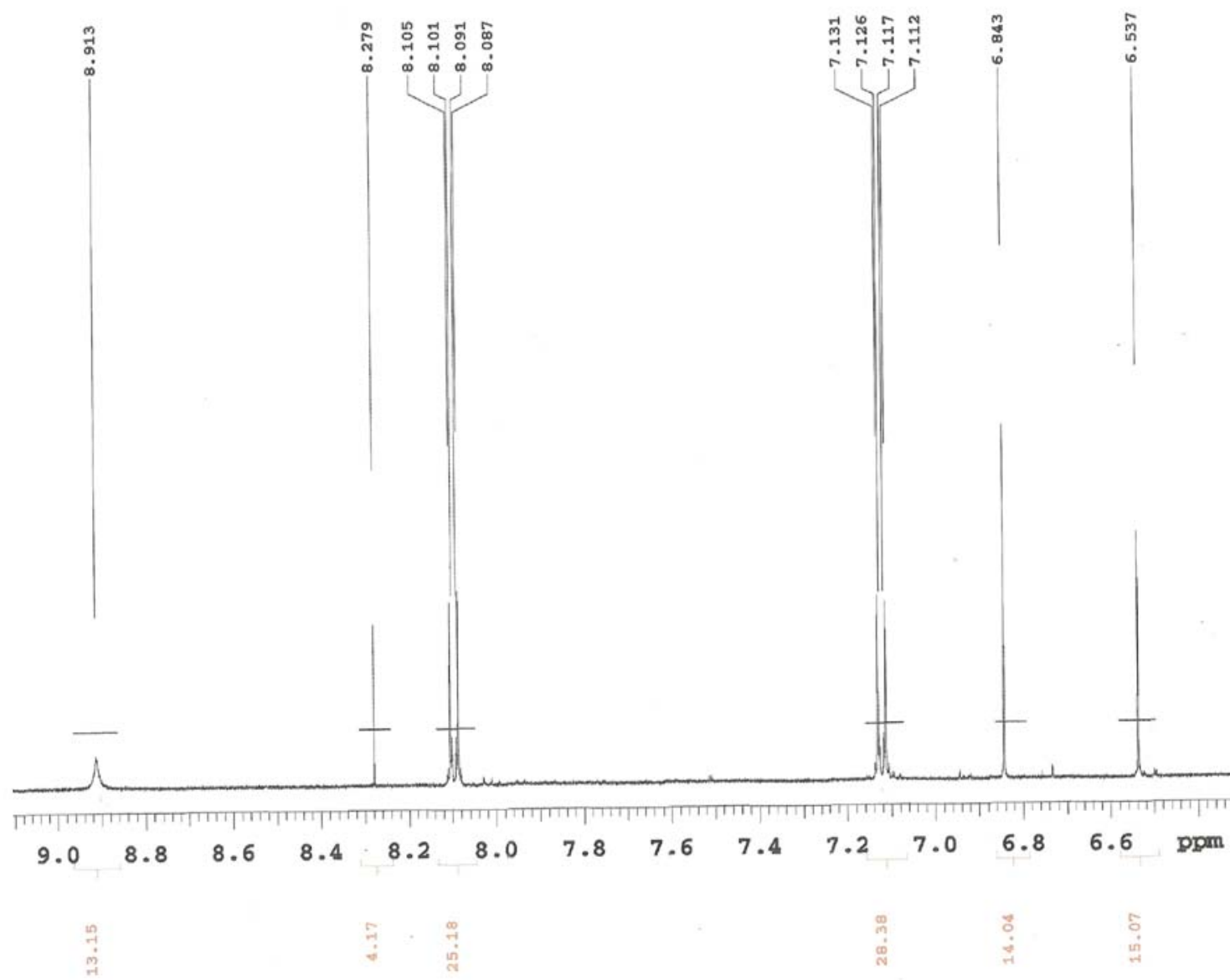

Figure 6S. Expansion of the ${ }^{1} \mathrm{H} N \mathrm{NR}$ spectrum of $5\left(\delta, D M S O-d_{6}, 500 \mathrm{MHz}\right)$ 


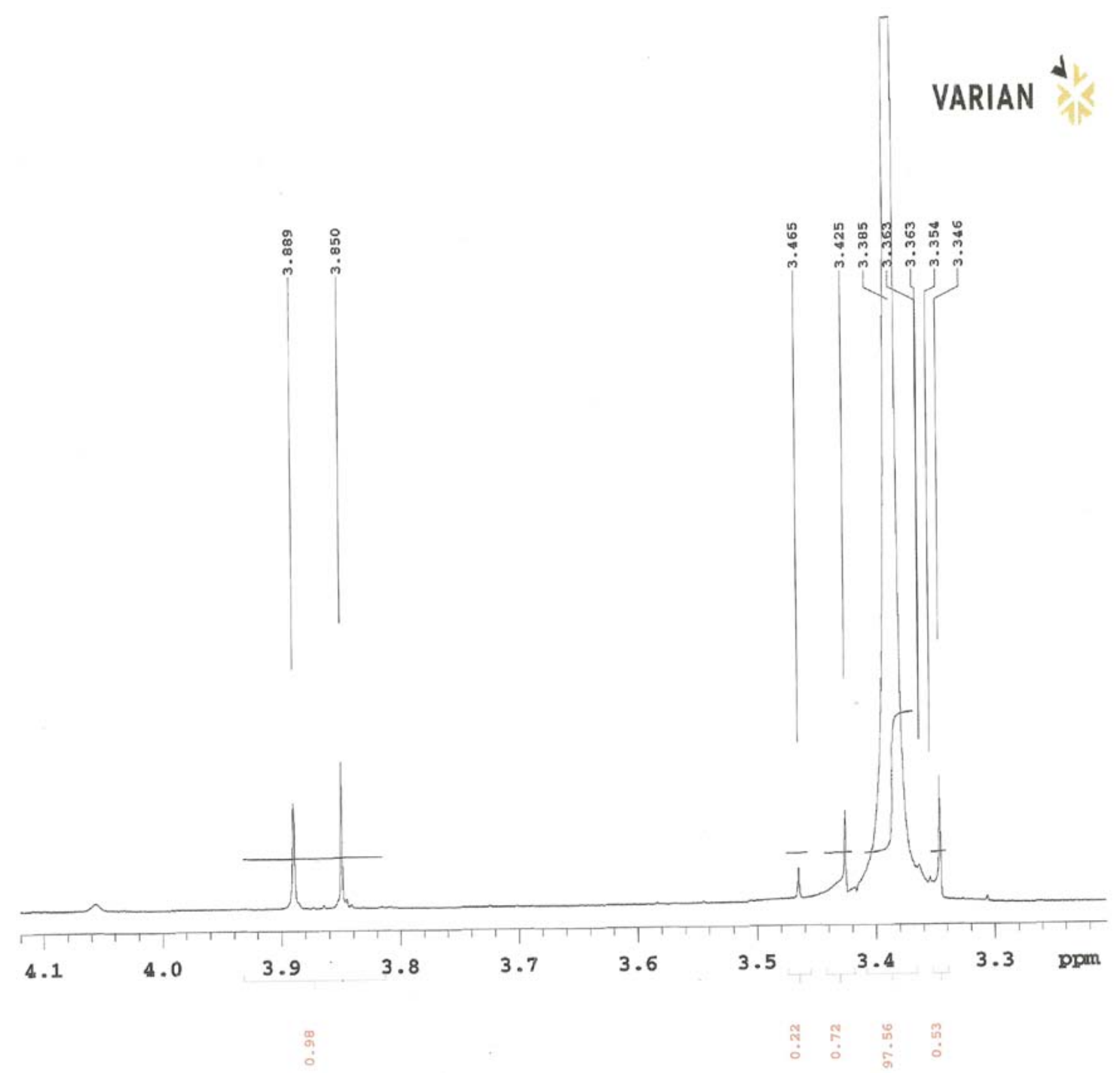

Figure 7S. Expansion of the ${ }^{1} \mathrm{H} N M R$ spectrum of $5\left(\delta, D M S O-d_{6}, 500 \mathrm{MHz}\right)$ 


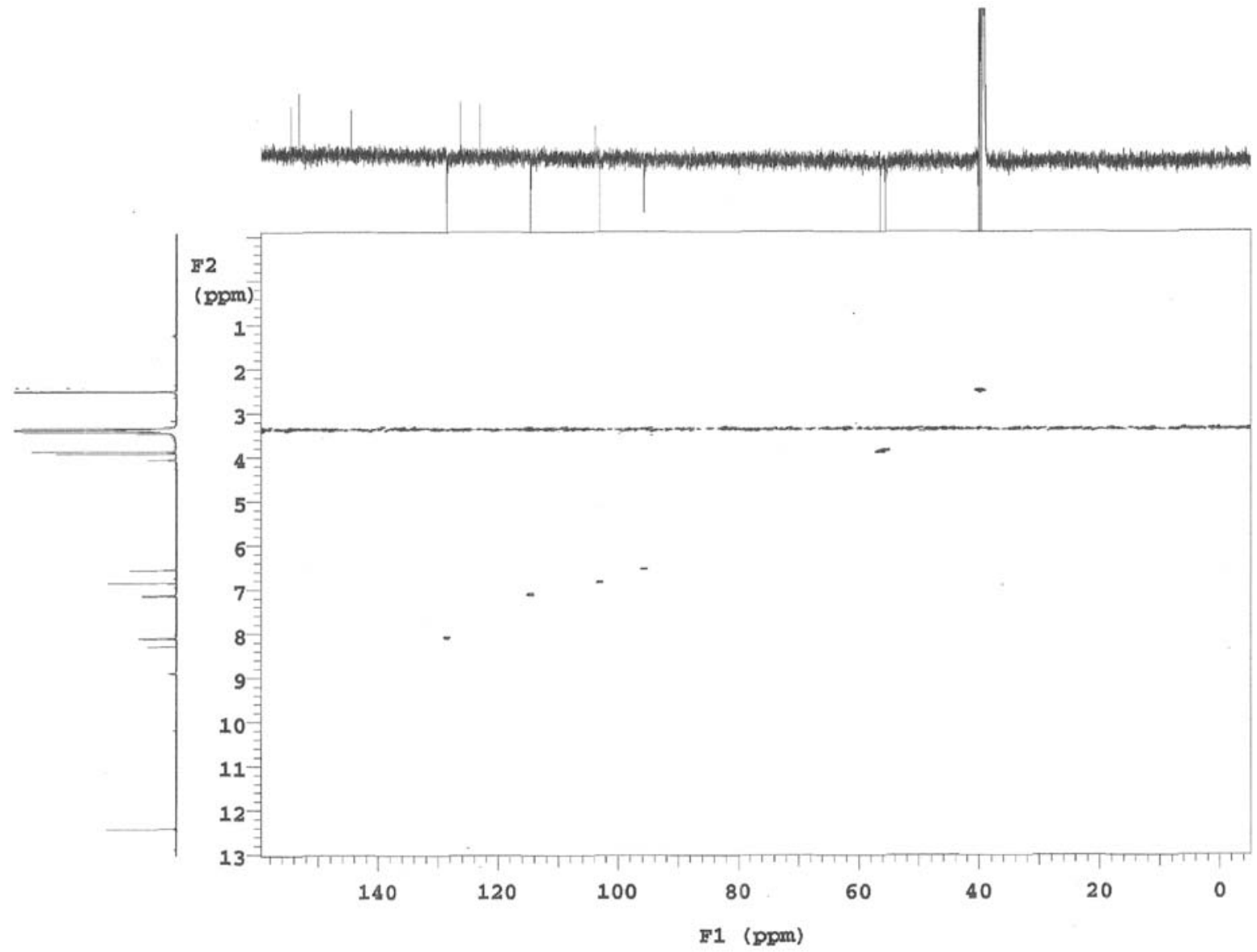

Figure 8S. ${ }^{1} \mathrm{H} x{ }^{13} \mathrm{C}-H M Q C$ NMR spectrum of $5\left(\delta, D M S O-d_{6}, 500 \mathrm{MHz}\right)$

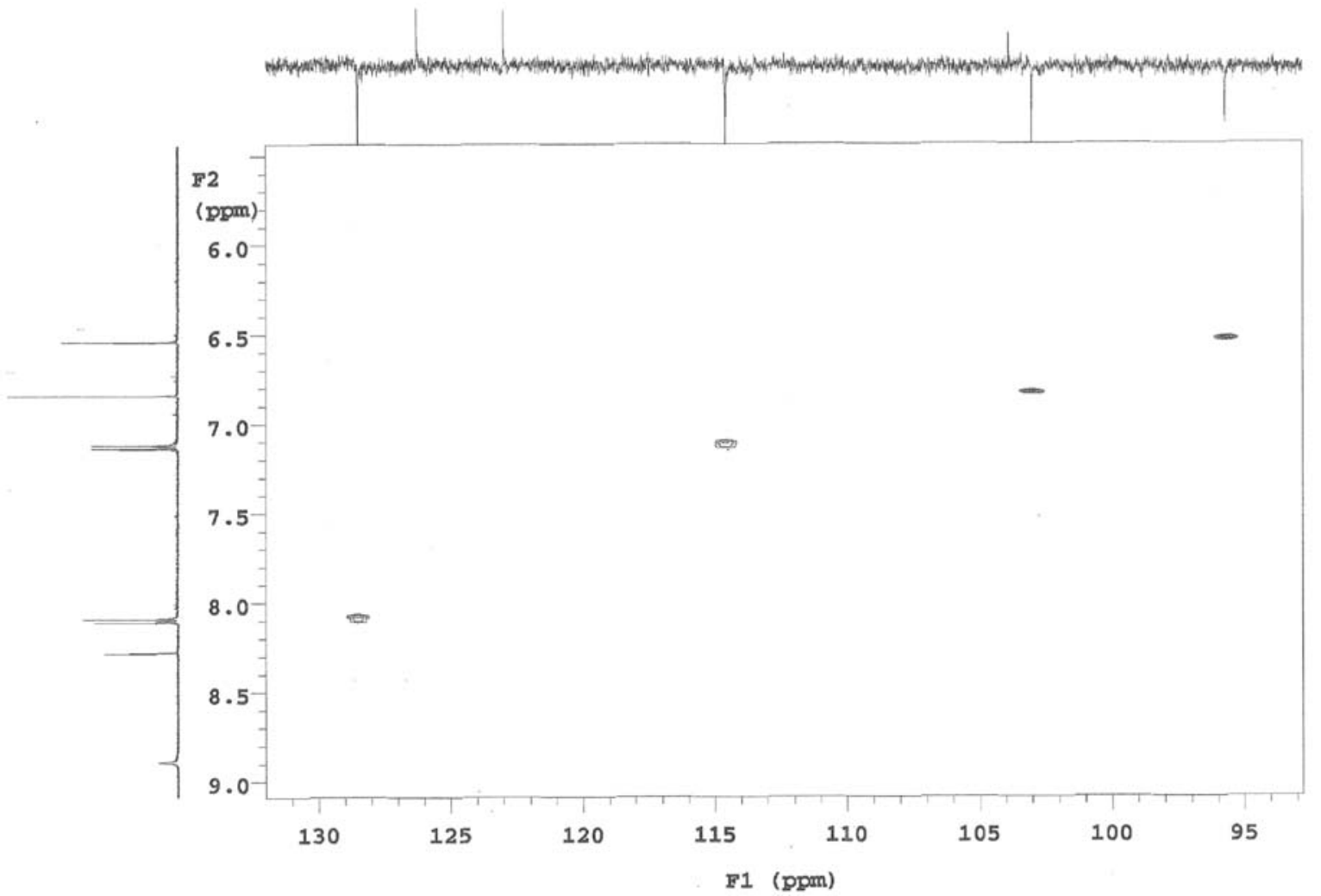

Figure 9S. Expansion of the ${ }^{1} \mathrm{H} x{ }^{13} \mathrm{C}-\mathrm{HMQC} N \mathrm{NM}$ spectrum of $5\left(\delta, D M S O-d_{6}, 500 \mathrm{MHz}\right)$ 


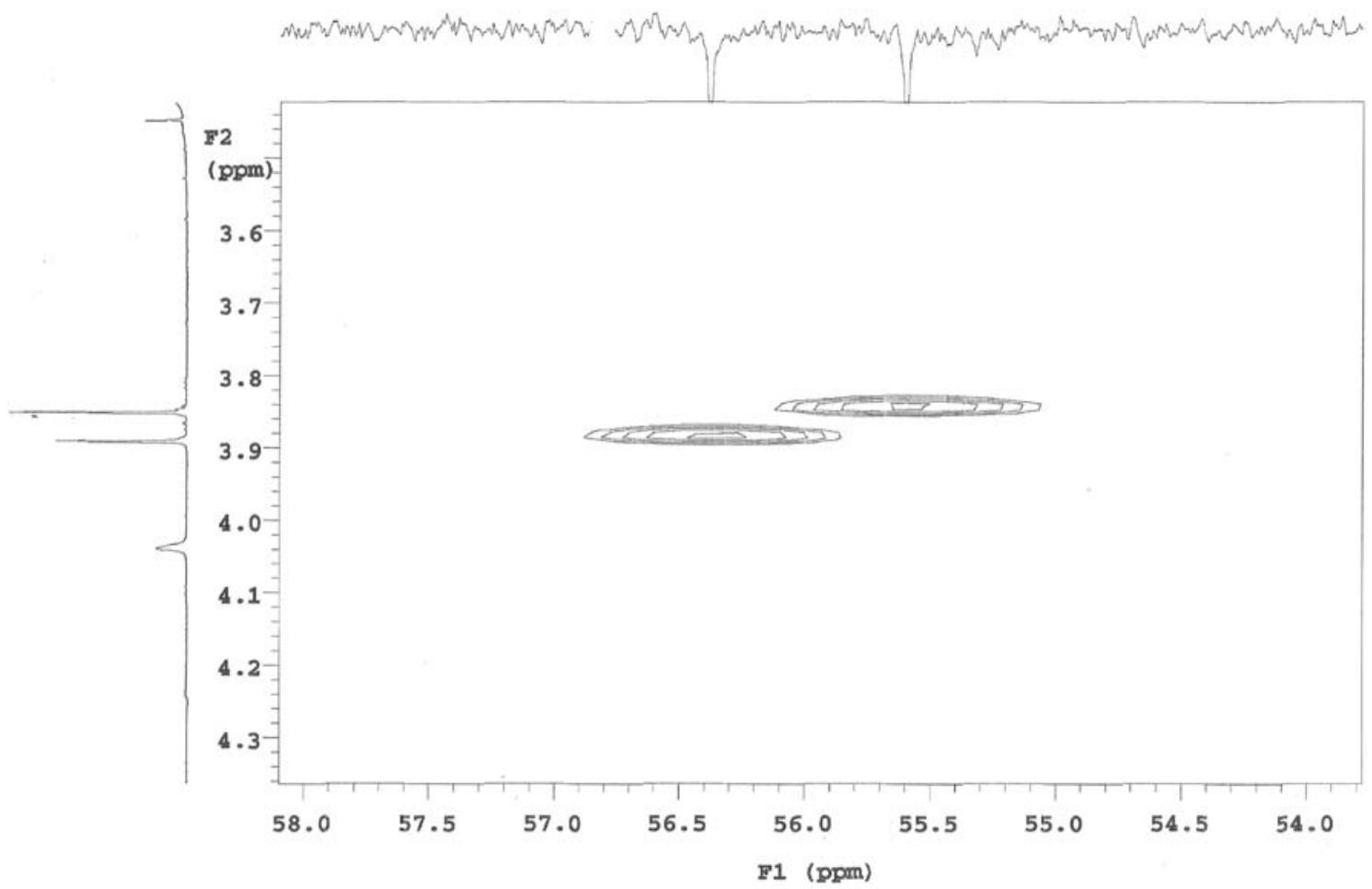

Figure 10S. Expansion of the ${ }^{1} \mathrm{H} x{ }^{13} \mathrm{C}-\mathrm{HMQC}$ NMR spectrum of $5\left(\delta, \mathrm{DMSO}-\mathrm{d}_{6}, 500 \mathrm{MHz}\right)$

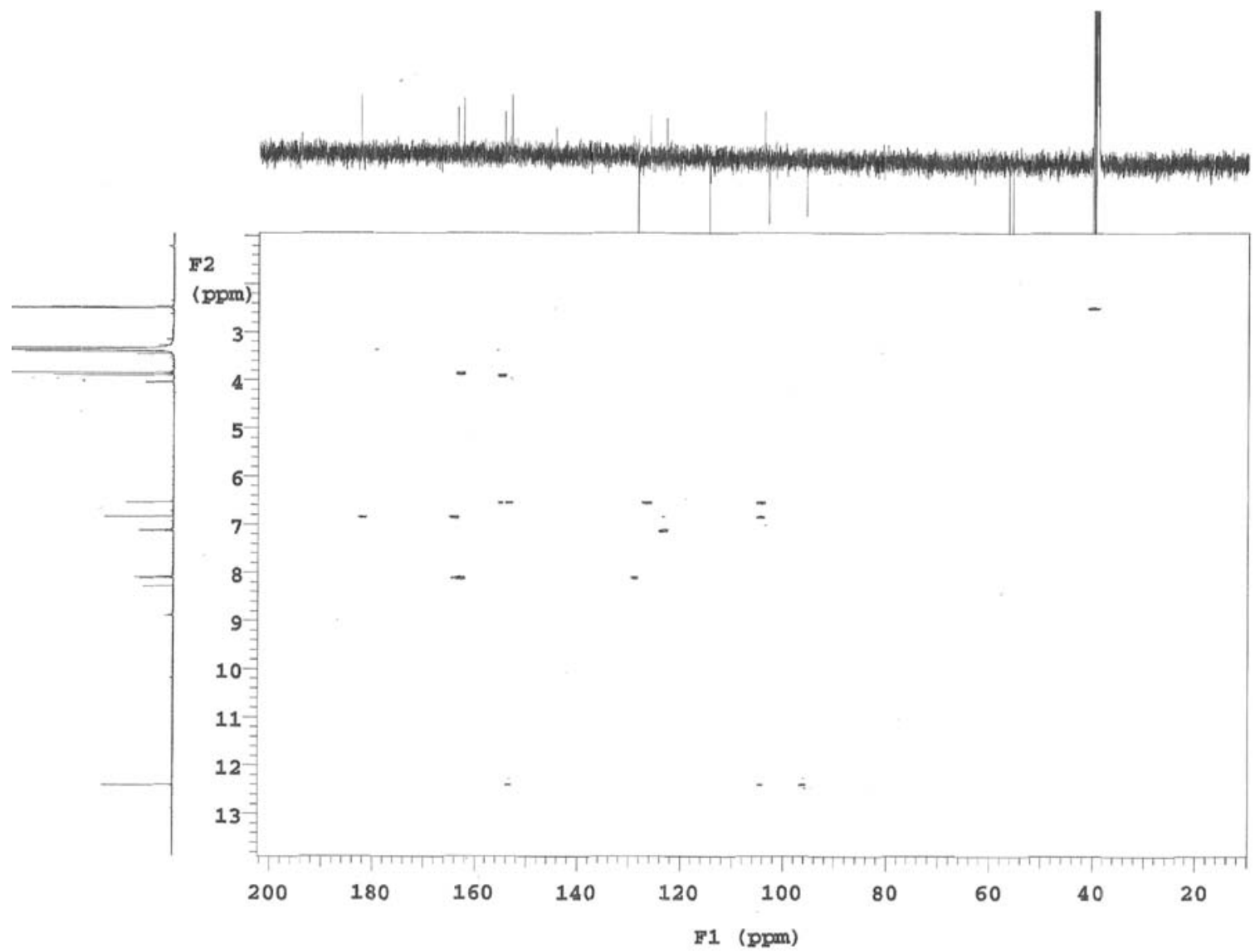

Figure 11S. ${ }^{1} \mathrm{H} \times{ }^{13} \mathrm{C}-\mathrm{HMBC}$ NMR spectrum of $5\left(\delta, D M S O-d_{6}, 500 \mathrm{MHz}\right)$ 


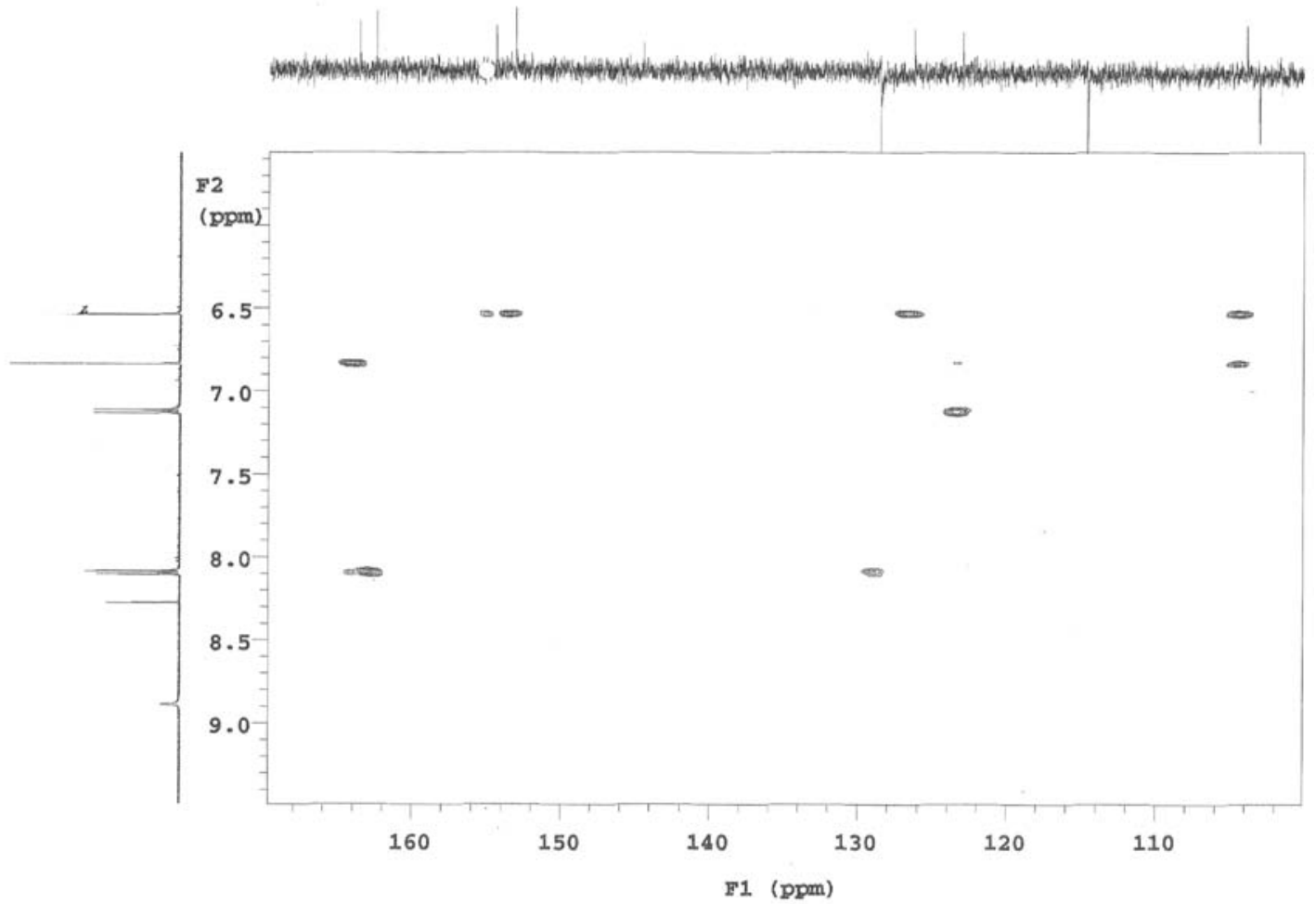

Figure 12S. Expansion of the ${ }^{1} \mathrm{H} x{ }^{13} \mathrm{C}-\mathrm{HMBC}$ NMR spectrum of $5\left(\delta, D M S O-d_{6}, 500 \mathrm{MHz}\right)$

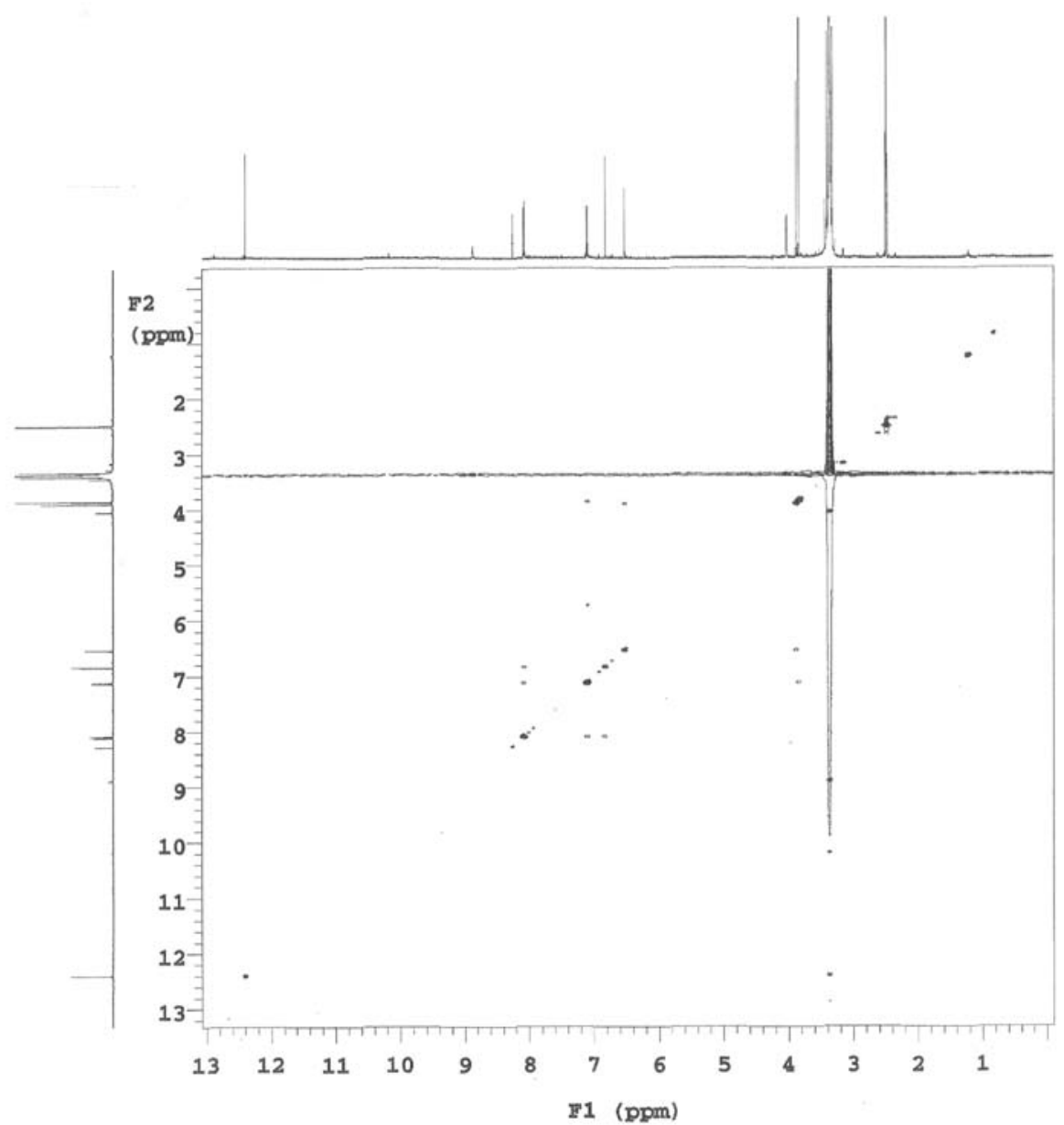

Figure 13S. ${ }^{1} \mathrm{H} x{ }^{1} \mathrm{H}$-NOESY NMR spectrum of $5\left(\delta, D M S O-d_{6}, 500 \mathrm{MHz}\right)$ 


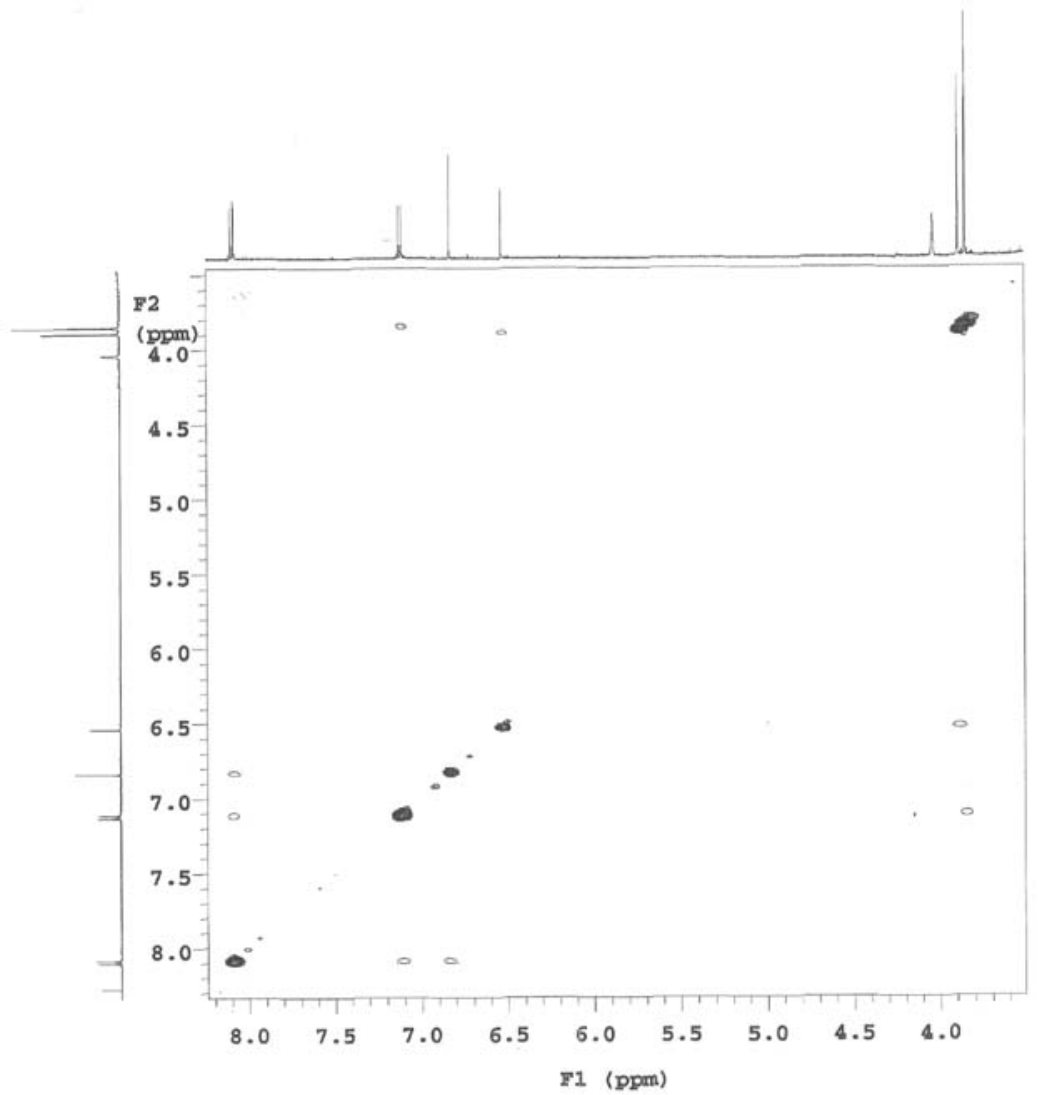

Figure 14S. Expansion of the ${ }^{1} \mathrm{H} x^{l} \mathrm{H}-\mathrm{NOESY}$ NMR spectrum of $5\left(\delta, D M S O-d_{6}, 500 \mathrm{MHz}\right)$

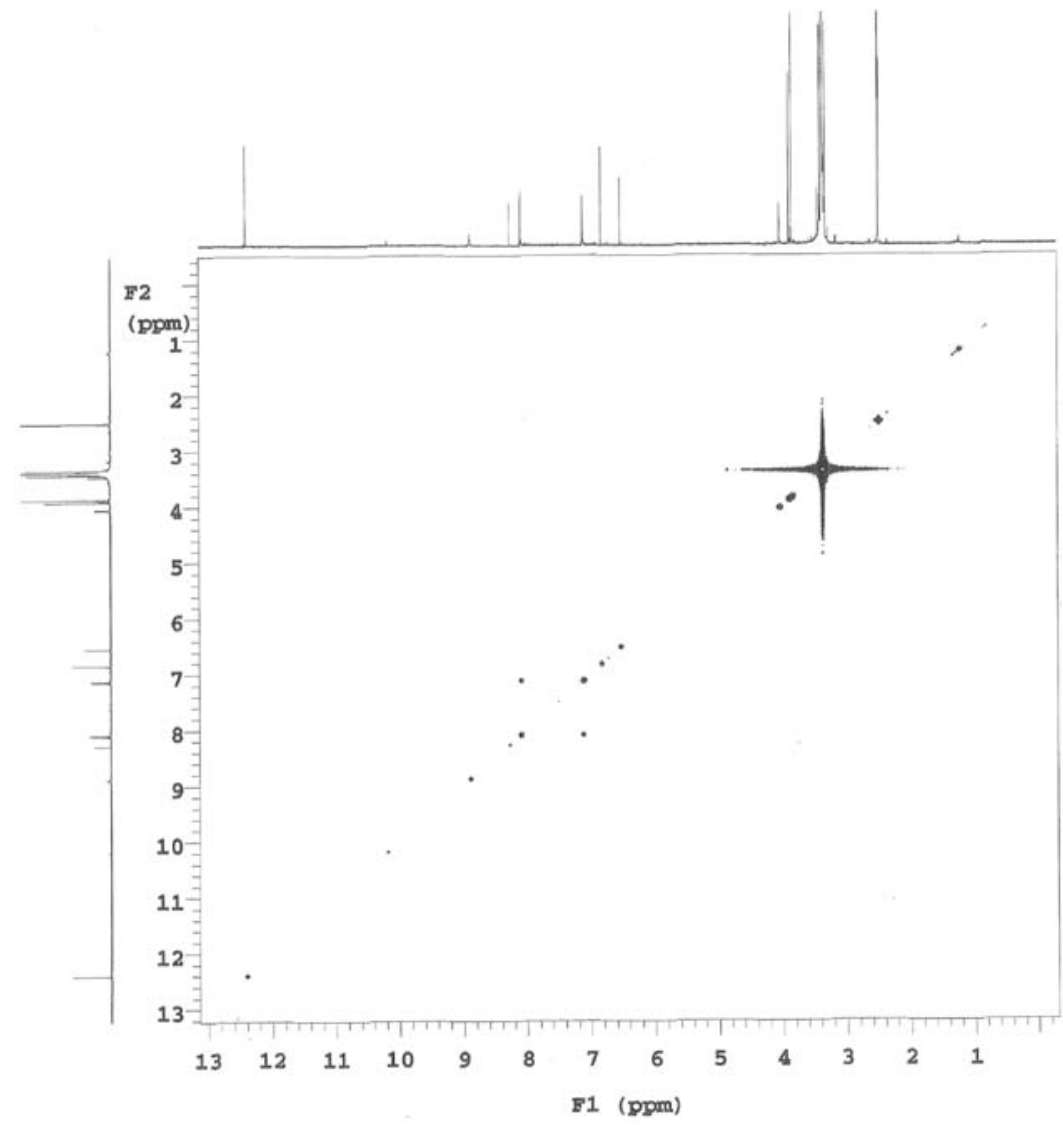

Figure 15S. ${ }^{1} \mathrm{H} x^{1} \mathrm{H}$-COSY NMR spectrum of $5\left(\delta, D M S O-d_{6}, 500 \mathrm{MHz}\right)$ 


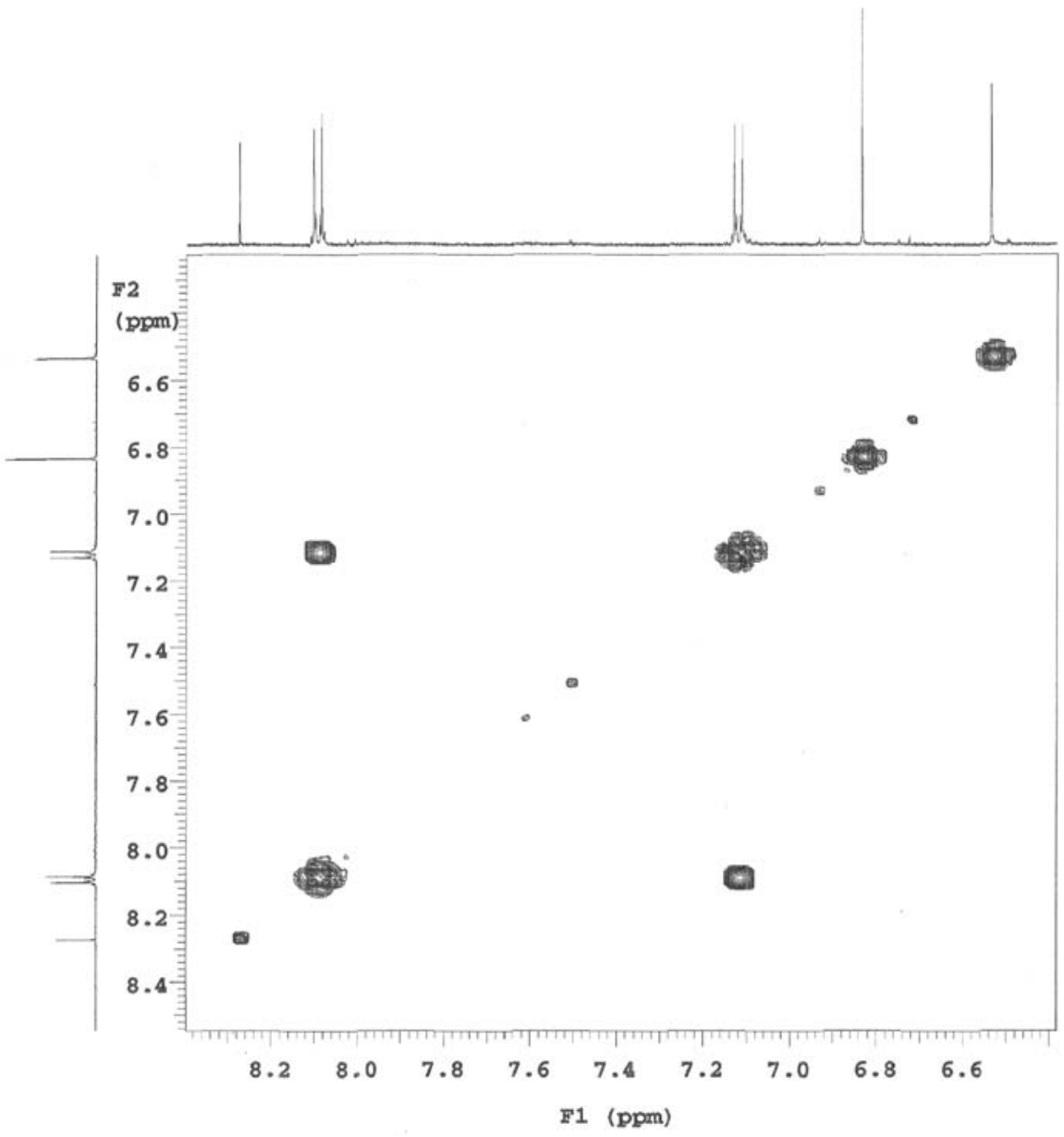

Figure 16S. Expansion of the ${ }^{1} \mathrm{H} x^{l} \mathrm{H}-\mathrm{COSY} \mathrm{NMR}$ spectrum of $5\left(\delta, D M S O-d_{6}, 500 \mathrm{MHz}\right)$ 